\title{
Switched-Capacitor Current-Fed Quasi-Z-Source Inverter
}

\author{
Andrii Chub, Oleksandr Husev \\ Department of Electrical Engineering \\ Tallinn University of Technology \\ Tallinn, Estonia \\ andrii.chub@ieee.org
}

\author{
Janis Zakis \\ Institute of Industrial Electronics and Electrical Engineering \\ Riga Technical University \\ Riga, Latvia \\ janis.zakis@ieee.org
}

\author{
Jacek Rabkowski \\ Institute of Control and Industrial Electronics \\ Warsaw University of Technology \\ Warsaw, Poland \\ jacek.rabkowski@isep.pw.edu.pl
}

\begin{abstract}
Focus of this study is on a new switched-capacitor current-fed (CF) quasi-Z-source inverter (qZSI) topology, which is derived from the conventional CF qZSI. Each capacitor of the quasi-Z-source network is replaced by a switching-capacitor cell built with two capacitors and three diodes. As our steady state analysis of an idealized converter shows, the proposed CF qZSI offers an extended regulation region and increased voltage gain. Bi-directional power transfer and a wide regulation range fit the requirements set for electric vehicle applications. Operation modes were verified by numerical simulation in PSIM.
\end{abstract}

Keywords-swithing-capacitors, current-fed inverters, quasi-Zsource inverters, steady-state analysis, buck-boost inverter.

\section{INTRODUCTION}

Invention of the Z-source inverters (ZSIs) [1] has started a broad research field of impedance-source (IS) single-stage buck-boost inverters [2]. Voltage-fed (VF) and current-fed (CF) ZSIs extend the operation range of voltage-source inverters (VSIs) and current-source inverters (CSI), respectively. ZSIs utilize conventional inverter stage that is coupled with the input by the Z-source network. Single stage solution has higher efficiency and lower price. Shoot-through and open states withstandability significantly improve the reliability of the VSIs and CSIs. Quasi-Z-source inverters (qZSIs) have been proposed to replace the ZSIs [3] that are further improvement of the IS technology. ZSIs suffer from high capacitor voltage stress in the VF topologies and high inductor current stress in the CF topologies. Moreover, ZSIs provide discontinuous input current. All these drawbacks are eliminated in the qZSIs, while all the advantages of the ZSIs are saved. Thanks to the all these features, qZSIs and DC/DC converters based on them have demonstrated high performance in the renewable energy systems [4], [5].

VSIs have been a conventional solution in DC/AC applications for many years while CSIs attracted little

This research work was financed by Estonian Ministry of Education and Research (project SF0140016s11), Estonian Research Council (Grant G8538), European Social Fund (Project Doctoral School of Energy and Geotechnology II), MOBILITAS Postdoctoral Research Grant (MJD391) and Latvian Council of Science (Grant 416/2012 and Grant 673/2014). attention mostly due to lack of suitable reverse-blocking (RB) switches [6]. In practice, each switch of the CSI is composed of a diode connected in series to the unidirectional voltage blocking switch, like an IGBT, and this leads to increased conduction losses. Almost the same situation is prevailing in the research on impedance-source inverters [6]. VF qZSIs are widely investigated, while CF qZSIs have attracted only few research groups [6]-[11]. However, CF qZSI shows much better properties than many of VF ZSIs/qZSIs, especially its bidirectional power transfer without an additional switch should be underlined. Current trends in the RB-IGBT development forecast forthcoming expansion of this market. Samples are currently available from several manufacturers, for example from Fuji Electric Device Technology Co. Ltd. [6], [9]. New semiconductor devices with reduced on-state voltage drop could make CSI-based converters attractive for new applications, like renewable energy conversion systems [12]. CF qZSIs have intrinsic shoot-through and open states protection, ability to control current directly, ruggedness, bidirectional power transfer [6]. These features fit several applications, like reactive power compensator, uninterruptable power supplies and adjustable speed drives.

Switched-capacitor (SC) and switched-inductor (SL) structures have been proposed in [13] to improve the performance of conventional converters in either step up or step down mode. SL structures were applied to VF ZSIs and qZSIs in order to improve step-up DC voltage gain characteristics [7], [14]-[15] while SC structure was previously applied to the CF ZSI in [7] to improved DC current gain in the voltage step down mode.

In this paper SC configuration for CF qZSI is proposed for the first time. Similarly, improved DC current gain is expected that should lead to the higher modulation index as compared to the conventional CF qZSI at the same conditions. This, in turn, will improve the quality of the inverter currents and decrease the filter size. 


\section{FUNDAMENTALS OF CF QZSI}

The conventional CF qZSI shown in Fig. 1a was proposed in [3]. It consists of the quasi-Z-source network (qZSN), the three-phase bridge and the output capacitive filter. The qZSN is composed of capacitors $C_{1} \ldots C_{2}$ and inductors $L_{1} \ldots L_{3}$. Neglecting ripples, currents through the inductors are nearly constant, assuming steady state conditions. During the switching period $T, \mathrm{CF}$ qZSI is in one of the three possible states: active, shoot-through or open state. Duration of the active state is $D_{A} \cdot T$. QZSN is connected to one or several output filter capacitors through the inverter stage. Capacitors discharge to the load, inductors supply the load. Energy stored in the elements of the qZSN decreases. An equivalent circuit is shown in Fig. 2a. Duration of the shoot-through state is $D_{S h} \cdot T$. The output of the qZSN is short-circuited. Capacitors discharge to the corresponding inductors. Thus, the energy of the inductors increases. An equivalent circuit is shown in Fig. 2b. Duration of the open state is $D_{O P} \cdot T$. The output of the qZSN is open. Inductors charge qZS capacitors. Thus, the energy of the inductors decreases. An equivalent circuit is shown in Fig. 2c.

Steady state analysis of the CF qZSI was performed in [6]. In fact, $D_{A}+D_{S h}+D_{O P}=1$ and voltage of the qZSN capacitors is equal to the input voltage: $V_{C}=V_{C 1}=V_{C 2}=V_{I N}$. DC voltage gain depends on the duty cycles of the active state and the open state:

$$
G_{V-C F q Z S I}=\frac{V_{O U T}}{V_{I N}}=\frac{1-2 \cdot D_{O P}}{D_{A}} .
$$

From (1) it follows that $D_{A}$ defines the step up operation, while $D_{O P}$ defines step down operation what means that $C F$ qZSI has buck-boost DC voltage gain characteristics. Since the qZSN is symmetrical, we can assume $I_{L 1}=I_{L 2}=I_{L}$. Then, the current ratio (DC current gain) depends only on $D_{O P}$ :

$$
G_{I-C F q Z S I}=\frac{I_{L}}{I_{I N}}=\frac{D_{O P}}{1-2 \cdot D_{O P}} .
$$

DC voltage gain in the step up mode is limited to two because it cannot exceed the voltage sum of the quasi-Zsource (qZS) capacitors voltage: $G_{V-C F q Z S I} \leq 2$. Maximum step up gain can be achieved when $D_{O P}=0$ and in this mode CF qZSI operates like a conventional CSI. When $D_{O P}=1-D_{A}$, it operates in a complete step down mode (shoot-trough states are eliminated). In this mode, CF qZSI feeding motor is in the motoring mode when $D_{A} \geq 0.5$, and in the energy regeneration mode when $D_{A} \leq 0.5$. This is an essential advantage of $\mathrm{CF}$
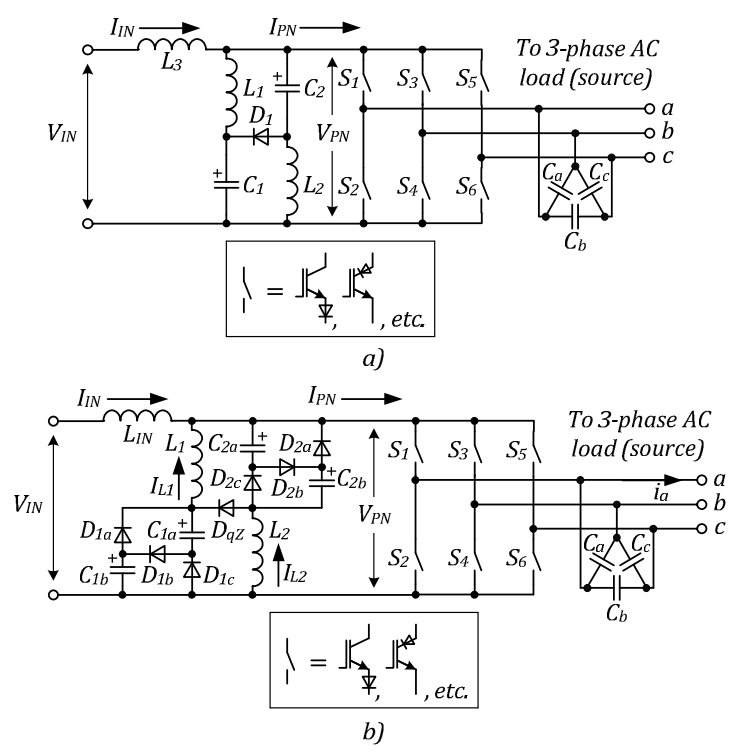

Fig. 1. Scheme of current-fed quasi-Z-source inverter (a) and proposed switched-capacitor current-fed quasi-Z-source inverter (b).

qZSI - it can work in the bi-directional mode without an additional switch, which is needed in VF qZSI [16].

\section{SWITCHED-CAPACITOR CURRENT-FED QZSI}

The novel switched-capacitor current-fed qZSI proposed in this paper is shown in Fig. 1c. Two capacitors of qZSN are replaced with the switched-capacitor cells: $C_{1 a}-C_{1 b}-D_{1 a}-D_{1 b^{-}}$ $D_{1 c}$ and $C_{2 a}-C_{2 b}-D_{2 a}-D_{2 b}-D_{2 c}$. This type of cells was proposed in [13] to improve the performance of step down converters. In the case of CF qZSI it spreads the regulation range in the buck mode, whereby bi-directional operation is improved.

The proposed SC CF qZSI is in one of the three possible states during the switching period, similarly to the conventional CF qZSI. During the active and the shootthrough state (Fig. $3 \mathrm{a}$ and $3 \mathrm{~b}$ ), diodes $D_{q Z}, D_{l b}$ and $D_{2 b}$ are off and capacitors in the switched-capacitor cells $C_{l a} / C_{l b}$ and $C_{2 a} / C_{2 b}$. discharge in parallel through the corresponding diodes $D_{l a} / D_{l c}$ and $D_{2 a} / D_{2 c}$. The situation is opposite during the open states (Fig. 3c). Diodes $D_{q Z}, D_{l b}$ and $D_{2 b}$ are conducting and these capacitors charge in series.

The following steady state analysis relies on these equivalent circuits and on an assumption that currents of the inductors are nearly constant. Furthermore, qZSN is assumed to be symmetrical: $L_{1}=L_{2}, C_{l a}=C_{l b}=C_{2 a}=C_{2 b}$. In this case currents and voltages in the qZSN are equal: $I_{L 1}=I_{L 2}=I_{L}$, $V_{C l a}=V_{C 1 b}=V_{C 2 a}=V_{C 2 b}=V_{C}$. Considering the volt-second balance over the switching period:
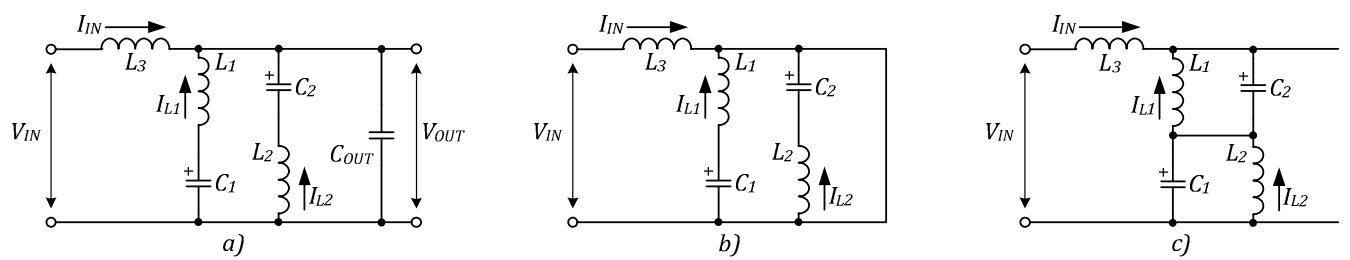

Fig. 2. Equivalent circuits of the CF qZSI in: a) active state, b) shoot-through state, and c) open state. 


$$
V_{I N}=\left(1-D_{O P}\right) \cdot V_{C}+2 \cdot D_{O P} \cdot V_{C}
$$

From (3) it follows that the capacitor voltage depends only on the duty cycle of the open state:

$$
V_{C}=\frac{V_{I N}}{1+D_{O P}} .
$$

The maximum input voltage of the inverter stage follows from (4) and Fig. 3c: $V_{P N \max }=4 \cdot V_{C}$. This is the main practical restriction to the topology in particular applications.

DC voltage gain could be found using the volt-second balance over the input inductor $L_{I N}$ : $V_{I N} \cdot\left(D_{A}+D_{S h}\right)-V_{O U T} D_{A}+\left(V_{I N}-V_{P N \max }\right) D_{O P}=0$. From this:

$$
G_{V-S C C F q Z S I}=\frac{V_{O U T}}{V_{I N}}=\frac{1-3 \cdot D_{O P}}{D_{A} \cdot\left(1+D_{O P}\right)}
$$

DC voltage gain factor cannot exceed two for a stable operation, as in the case of the CF qZSI. From the amperesecond balance of the qZSN capacitors: $I_{L} / 2\left(1-D_{O P}\right)=\left(I_{L}+I_{I N}\right)$ $D_{O P}$ and DC current gain can be expressed as follows:

$$
G_{I-S C C F q Z S I}=\frac{I_{L}}{I_{I N}}=\frac{2 \cdot D_{O P}}{\left(1-3 \cdot D_{O P}\right)} .
$$

Both equations (5) and (6) describing the gains of the inverter differ from those presented in [6] for CF qZSI. Thus, a series of characteristics was determined and drawn to show the features of the proposed system in reference to CF qZSI. First, the 3D plot of the surface defined by (5) is shown in
Fig. 4a. It displays how the DC voltage gain of the proposed SC CF qZSI depends on the duty cycles of the active and open states. Projection of this surface is shown in Fig. 4b, which shows the dependence of the DC voltage gain versus the duty cycle of the active state. It should be noted that it can possess any value inside the filled region. Moreover, the given value of the voltage gain may be set with different values of $D_{A}$.

Comparison of the DC voltage gain of $\mathrm{CF}$ qZSI and $\mathrm{SC} \mathrm{CF}$ qZSI is shown in Fig. 4c. The area between the curves $a$ and $b$ is the regulation range of CF qZSI, while the area between the curves $a$ and $c$ is the regulation range of SC CF qZSI. The filled region shows how $\mathrm{SC}$ improves the regulation range of the proposed qZSI. The given value of the voltage gain may be obtained with a higher value of $D_{A}$, however the introduced $\mathrm{SC}$ cells do not affect the inverter operation in the boost mode (gain $>1$ ). On the other hand, maximum available gain for negative values increases from 3 to 4 . Finally, DC current gains are compared in Fig. $4 \mathrm{~d}$. The proposed qZSI operates in the buck-boost mode in the region $D_{O P} \leq 1 / 3$, while the conventional CF qZSI has a wider range of the buck-boost operation: $D_{O P} \leq 1 / 2$. It means that SC CF qZSI has a wider regulation range for the modulation index of the reference signal (sinusoidal). Numerical simulation showed that $D_{O P}$ cannot be equal to zero for the proposed converter because the $\mathrm{SC}$ cell needs an open state to ensure the ampere-second balance. Also, due to the same reason, in the boost mode, currents could be discontinuous that leads to more complicated behavior and requires additional analysis.

\section{Simulation Results}

Numerical simulation in PSIM was performed in order to verify buck and boost operations of the SC-CF qZSI. Simulation was done according to the circuit from Fig. 1c. The following parameters were used: $L_{I N}=L_{1}=L_{2}=2 \mathrm{mH}$, $C_{l a}=C_{1 b}=C_{2 a}=C_{2 b}=60 \mathrm{uF}, \quad C_{a}=C_{b}=C_{c}=25 \mathrm{uF}$. Three resistors of $15 \mathrm{Ohm}$ each connected in the star configuration
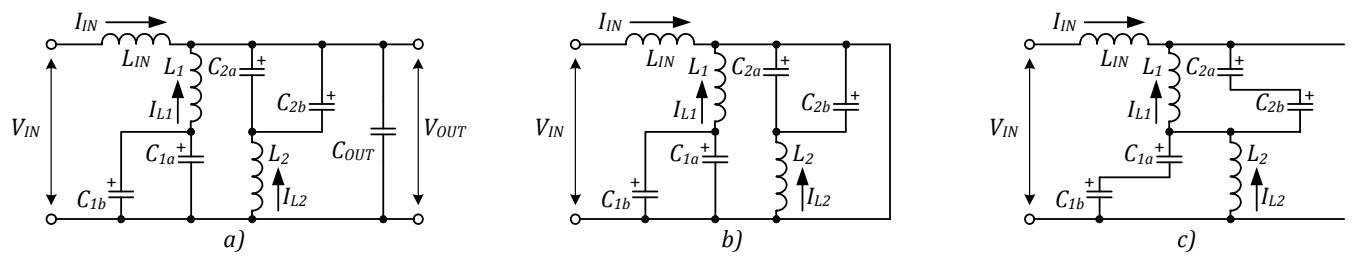

Fig. 3. Equivalent circuits of the SC CF qZSI in: a) active state, b) shoot-through state, and c) open state.

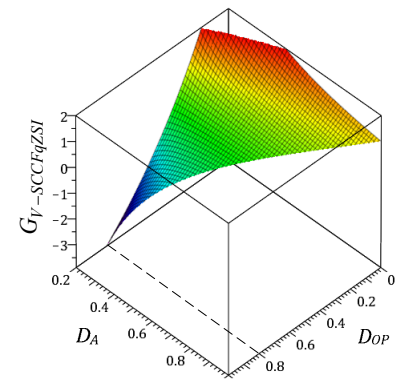

a)

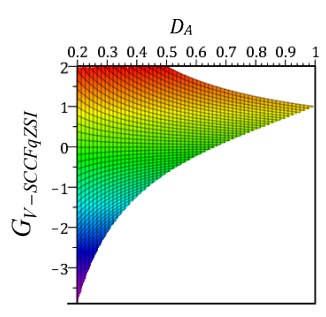

b)

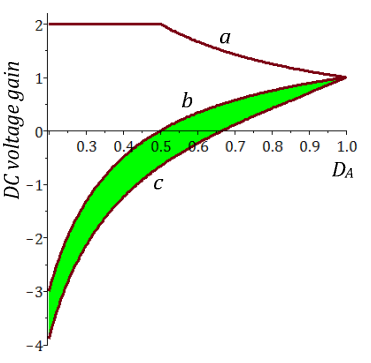

c)

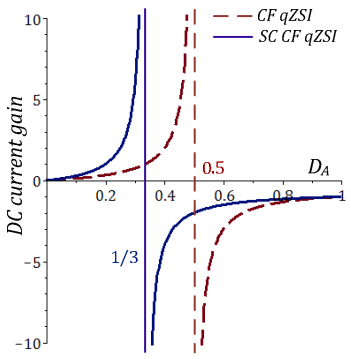

d)

Fig. 4. DC voltage and current plots of CF qZSIs: a) DC voltage gain surface for SC CF qZSI, b) projection of the DC voltage gain surface of CF qZSI, c) DC voltage gain comparison, and d) DC current gain comparison. 
comprise the load. Switches have $3 \mathrm{~V}$ saturation voltage and diodes have $2 \mathrm{~V}$ forward voltage drop. Switching frequency equals $30 \mathrm{kHz}$. For the inverter control, sinusoidal PWM based on on-line pattern generator was proposed in [17] and modified simple boost control (commonly used for VF qZSI) was applied with the grid frequency $50 \mathrm{~Hz}$. The inverter was tested for two input voltage values: $200 \mathrm{~V}$ for boost operation and $400 \mathrm{~V}$ for buck operation. The output voltage (peak lineto-line voltage) should be the same in both cases $(300 \mathrm{~V})$. Simulated waveforms for buck and boost modes are shown in Figs. 5 and 6. Simulated average values of currents and voltages are presented in Table I. Simulation proves the buckboost characteristics of the proposed SC CF qZSI. For this topology, the DC current gain is the key parameter. Our theoretical analysis clearly predicts its simulated values.

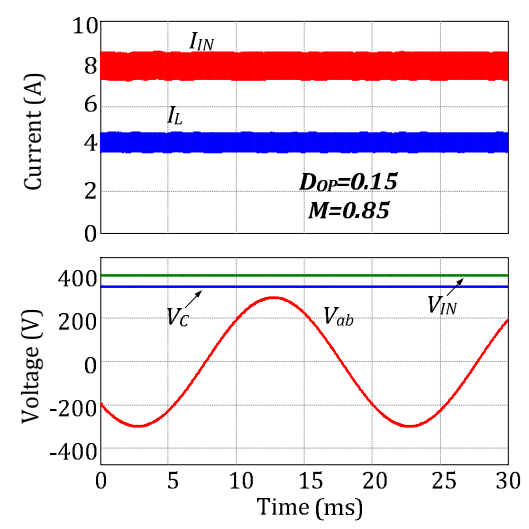

Fig. 5. Simulated waveforms for the buck mode $\left(V_{I N}=400 \mathrm{~V}\right)$.

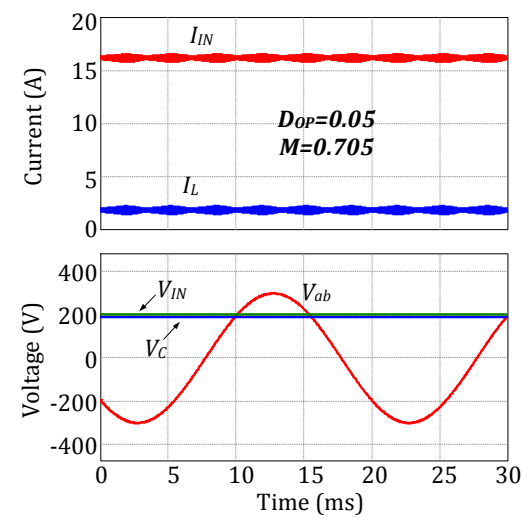

Fig. 6. Simulated waveforms for the boost mode $\left(V_{I N}=200 \mathrm{~V}\right)$.

TABLE I. SIMULATION RESUlTS

\begin{tabular}{|c|c|c|}
\hline Parameters & Boost mode & Buck mode \\
\hline$V_{I N}$ & $200 \mathrm{~V}$ & $400 \mathrm{~V}$ \\
\hline$I_{I N}$ & $16.25 \mathrm{~A}$ & $7.93 \mathrm{~A}$ \\
\hline$V_{a b}(\mathrm{RMS})$ & $212 \mathrm{~V}$ & $211 \mathrm{~V}$ \\
\hline$V_{C}$ (calculated) & $190.7 \mathrm{~V}(190.5 \mathrm{~V})$ & $349 \mathrm{~V}(347 \mathrm{~V})$ \\
\hline$I_{L}$ & $1.91 \mathrm{~A}$ & $4.32 \mathrm{~A}$ \\
\hline$G_{I}$ (calculated) & $0.118(0.118)$ & $0.54(0.55)$ \\
\hline
\end{tabular}

\section{CONCLUSIONS}

Our theoretical analysis shows the buck-boost DC voltage gain characteristics and a wide regulation range of the proposed inverter proven by simulation. These features and possibility of bi-directional operation fit electric vehicle (EV) applications. The SC cell used in the qZSN is intended for buck operation. Further research will address limitations in the boost mode imposed by ampere-second balance in the SC cell. Possibilities of the proposed qZSI use in electric vehicles and variable-speed motor drives will be investigated.

\section{REFERENCES}

[1] Fang Zheng Peng, "Z-source inverter," IEEE Trans. Ind. Appl., vol. 39, no. 2, pp. 504-510, Mar/Apr 2003.

[2] Y.P. Siwakoti, F. Peng, F. Blaabjerg, P. Loh, G.E. Town, "Impedance Source Networks for Electric Power Conversion Part-I: A Topological Review," IEEE Trans. on Power Electron., in press.

[3] J. Anderson, F. Peng, "Four quasi-Z-Source inverters," PESC 2008, pp. 2743-2749.

[4] Yuan Li, J. Anderson, F.Z. Peng, Dichen Liu, "Quasi-Z-Source Inverter for Photovoltaic Power Generation Systems," APEC 2009, pp. 918-924.

[5] D. Vinnikov, I. Roasto, "Quasi-Z-Source-Based Isolated DC/DC Converters for Distributed Power Generation," IEEE Trans. Ind. Electron., vol. 58, no. 1, pp. 192-201, Jan. 2011.

[6] Shuitao Yang, F.Z. Peng, Qin Lei, R. Inoshita, Zhaoming Qian, "Current-Fed Quasi-Z-Source Inverter With Voltage Buck-Boost and Regeneration Capability," IEEE Trans. Ind. Appl., vol. 47, no. 2, pp. 882-892, March-April 2011.

[7] Ding Li, Poh Chiang Loh, Miao Zhu, Feng Gao, F. Blaabjerg, "Generalized Multicell Switched-Inductor and Switched-Capacitor ZSource Inverters," IEEE Trans. Power Electron., vol. 28, no. 2, pp. 837-848, Feb. 2013.

[8] D. Cao, Qin Lei, F.Z. Peng, "Development of high efficiency current-fed quasi-Z-source inverter for HEV motor drive," APEC 2013, pp. 157-164.

[9] S. Yang, Q. Lei, F. Peng, R. Inoshita, Z. Qian, "Current-fed quasi-Zsource inverter with coupled inductors," ECCE 2009, pp. 3683-3689.

[10] Qin Lei, Dong Cao, F.Z. Peng, "Novel SVPWM switching pattern for high efficiency $15 \mathrm{KW}$ current-fed quasi-Z-source inverter in HEV motor drive application," APEC 2012, pp. 2407-2420.

[11] Xu Peng Fang, Zhi Qiao Chen, Xu Guang Wang, "Current-fed quasi-Zsource inverter-based adjustable speed drive system(ASDs)," ASEMD 2013, pp. 215-216.

[12] D. M. Whaley, G. Ertasgin, W. L. Soong, N. Ertugrul, J. Darbyshire, H. Dehboeni, C. V. Nayar, "Investigation of a Low-Cost Grid-Connected Inverter for Small-Scale Wind Turbines Based on a Constant-Current Source PM Generator," IECON 2006, pp. 4297-4302.

[13] B. Axelrod, Y. Berkovich, A.Ioinovici, "Switched-Capacitor/SwitchedInductor Structures for Getting Transformerless Hybrid DC-DC PWM Converters," IEEE Trans. Circuits Syst. I, Reg. Papers, vol. 55, no. 2, pp. 687-696, March 2008.

[14] Minh-Khai Nguyen, Young-cheol Lim, Geum-Bae Cho, "SwitchedInductor Quasi-Z-Source Inverter," IEEE Trans. on Power Electron., vol. 26, no. 11, pp. 3183-3191, Nov. 2011.

[15] M.-K. Nguyen, Y.-C. Lim, J.-H. Choi, "Two switched-inductor quasi-Zsource inverters," IET Power Electronics, vol. 5, no. 7, pp. 1017-1025.

[16] J. Zakis, D. Vinnikov, I. Roasto, L. Ribickis, "Quasi-Z-source inverter based bi-directional DC/DC converter: Analysis of experimental results," CPE 2011, pp. 394-399.

[17] J.R. Espinoza, G. Joos, "Current-source converter on-line pattern generator switching frequency minimization," IEEE Trans. on Ind. Electron., vol. 44, no. 2, pp. 198-206, Apr 1997. 